\title{
NANOFIBRILLATED CELLULOSE APPLIED AS REINFORCEMENT FOR SHORT-FIBER PAPER
}

\author{
Daniele Cristina Potulski ${ }^{1 *}$, Lívia Cássia Viana ${ }^{2}$, Ana Namikata da Fonte ${ }^{3}$ Mayara Elita Carneiro ${ }^{4}$, Graciela Ines \\ Bolzon de Muniz ${ }^{5}$, Umberto Klock ${ }^{6}$
}

\begin{abstract}
Universidade Federal do Paraná. Curitiba, Paraná, Brasil - danielepotulski@gmail.com ${ }^{1 *}$; ana.namikata@gmail.com³ mayaraecarneiro@gmail.com ${ }^{4}$; graciela.ufpr@gmail.com ${ }^{5}$; klockuer@gmail.com ${ }^{6}$
\end{abstract}

${ }^{2}$ Universidade Federal do Tocantins. Gurupi, Tocantins, Brasil -e-mail: livia.viana@uft.edu.br

Received for publication: 02/05/2018 - Accepted for publication: 31/10/2019

\begin{abstract}
Resumo
Nanocelulose aplicada como reforço para papel de fibra curta. Este trabalho teve como objetivo avaliar a influência da adição de diferentes porcentagens de celulose nanofibrilada sobre as propriedades mecânicas e físicas do papel feito a partir da polpa de fibras curtas. A celulose nanofibrilada foi obtida a partir de polpa Kraft de Eucalyptus sp. branqueada, submetida a três diferentes passes no moinho: 2, 10 e 20 passes. Os papéis foram produzidos com a adição de celulose nanofibrilada nas porcentagens de 3, 6 e $9 \%$. Os resultados mostraram que a adição de celulose nanofibrilada aumentou as propriedades mecânicas: índice de tração, índice de arrebentamento e índice de rasgo. A porosidade e a densidade aparente diminuíram. A adição de $9 \%$ de celulose nanofibrilada, obtida a partir de 2 passes, proporcionou os melhores resultados com aumento da resistência à tração, arrebentamento e rasgo de 111, 114 e 70\%, respectivamente, em comparação aos papéis normais. A melhoria das propriedades mecânicas do papel está relacionada à rede muito densa de ligações de hidrogênio, resultando em maior área de superfície obtida após a desfibrilação. A nanocelulose apresenta potencial para ser aplicada na melhoria da qualidade do papel e como agente de reforço em compósitos.

Palavras chave: nanofibras, CNF, polpa celulósica, propriedades mecânicas, Eucalyptus
\end{abstract}

\begin{abstract}
In this work we studied the influence on the mechanical and physical properties of paper made from short-fiber pulp by adding different percentages of nanofibrillated cellulose. Bleached Eucalyptus sp. Kraft pulp was submitted to three different grinding regimes to obtain the nanofibrillated cellulose of 2, 10 and 20 passes through the grinder. Paper was produced by incorporating nanofibrillated cellulose in the proportions of 3, 6 and $9 \mathrm{wt} \%$. The results showed that the addition of nanofibrillated cellulose increased the following mechanical properties: tensile index, tear index, and burst index. The porosity and the apparent density decreased. The addition of $9 \%$ of nanofibrillated cellulose obtained from 2 grinding passes provided the best results with improvements in tensile, burst and tear resistance of 111,114 and $70 \%$, respectively, in comparison to normal paper. The improvement in the mechanical properties of paper is related to the very dense network of hydrogen bonds, resulting in greater surface area obtained after defibrillation. Nanofibrillated cellulose can be applied to improve paper quality and for reinforcing composites.

Keywords: Nanofibrils, NFC, pulp, mechanical properties, Eucalyptus.
\end{abstract}

\section{INTRODUCTION}

Wood is chemically composed of cellulose, hemicellulose, lignin, extractives and ash. The percentages of each component vary according to species, fiber type, tree position, growth condition, age and extraction methods. Cellulose is present in the greatest percentage among these materials, representing about $40-45 \%$ of the total wood mass (FENGEL; WEGENER, 1984).

Successful use of cellulose from different sources has been reported to produce new sustainable products or as a substitute for other polymers (CHEN et al., 2017). The products obtained from cellulose are biodegradable, low density, environmentally friendly and low cost, and have good physical and mechanical properties (MOHAMMADKAZEMI et al., 2015).

Pinus sp. and Eucalyptus sp. are the most used species for long- and short-fiber pulping in Brazil, respectively. These species grow rapidly in addition to having good technological properties for pulp and paper production (such as mechanical and physical properties). Brazil's planted forests have the highest productivity and shortest rotation in the world. These high rates are the result of the climate and soil conditions, as well as continuous investments by companies in the country (IBA, 2017). Eucalyptus species are mainly used to produce bleached pulp for writing, printing and tissue paper, accounting for about $87 \%$ of pulp production in Brazil (IBA, 2017).

In the context of sustainable development, the sector has an advantage in relation to global competition as all pulp and paper production in the country is from planted forests. Considering the global cellulose fiber

FLORESTA, Curitiba, PR, v. 50, n. 3, p. 1411 - 1420, jul/set 2020.

Potulski, D. C. et.al.

ISSN eletrônico 1982-4688

DOI: $10.5380 /$ rf.v50 i3. 59251 
market, Brazil is the one of the largest suppliers of cellulose fiber and finished products made from it such as packaging, printing and writing paper, and paperboard (IBA, 2017).

The pulp and paper sector has been investing in research with the purposes of creating new products, better use of by-products, reducing inputs in the production process and improving the quality of products. Studies with nanofibrillated cellulose (NFC) indicate the material as an excellent input in the pulp and paper industry (GONZÁLEZ et al., 2012; POTULSKI et al., 2018). NFC can be used to replace chemical additives, reduce refining time and improve paper properties.

NFC enables producing paper with higher density, better mechanical properties, low porosity, excellent oxygen barrier properties and less water absorption (JONOOBI et al., 2012; POTULSKI, et al. 2018). One of the reasons for the increase in the mechanical properties of NFC-produced paper is the improvement of interfibrillar bonding, which reduces porosity and increases the density of these paper products (KHALIL et al., 2014). González et al. (2012) studied nanofibrillated cellulose obtained by a combination of chemical treatment and mechanical processing and observed an increase in the mechanical properties of the paper.

Recent research shows nanofibrillated cellulose as a reinforcement in composite materials due to its high resistance and rigidity and low weight. The larger contact surface between the adjacent cellulose fibers provides a higher number of hydrogen bonds, forming a denser network. This fact promotes outstanding mechanical properties, biocompatibility, transparency and high reactivity (ZIMMERMAN et al., 2010). These have been studied for polymer applications in the packaging, biomedicine, adhesive, fiber, electronics and automotive industries (ZIMMERMAN et al. 2010).

Nanofibrillated cellulose is recognized as having potential in the field of pulp and paper technology. There is also research interest on its use in papermaking, coating and films. Many studies have shown that NFC can be applied as strength additives for paper to enhance barrier properties in food packaging, to improve paper gloss, to reduce paper grammage and for smart and sustainable packaging (YOO; HSIEH, 2010). NFC has an advantage in use due to its relative abundance, renewability, biodegradability, high specific surface area, high aspect ratio, high strength and stiffness, and low weight (OSONG et al. 2016).

In this context, this work aimed to evaluate the incorporation of different percentages of nanofibrillated cellulose (NFC) in short-fiber paper to reinforce paper sheets.

\section{MATERIAL AND METHODS}

\section{Material}

Eucalyptus sp. (Kappa no. = 50.9) material was used to obtain the nanofibrillated cellulose and bleached Eucalyptus sp. Kraft (Kappa no. = 3.5) commercial pulp was used to make paper.

\section{Obtaining Nanofibrillated Cellulose (NFC)}

Nanofibrillated cellulose (NFC) was obtained from Eucalyptus sp. cellulose pulp, which was first dispersed in water and disintegrated for five minutes to obtain a homogeneous suspension of fibers with water concentration of $1 \%$ by dry mass. This suspension was subjected to mechanical defibrillation in a Masuko Sangyo Super Masscolloider (MKCA6-3), with 2, 10 and 20 passes through a grinder at 1500 rpm rotation.

\section{Microscopic Characterization}

The NFC was characterized by transmission electron microscopy analysis to visualize the dimensions and appearance of the fibrillar structures. Each sample was solubilized in water and deposited on a grid with 200 mesh size and then dried to perform the characterization. The samples were kept at room temperature for solvent evaporation to form a film. The images were acquired in a JEOL 1200EXII electron microscope using a magnification of $15,000 \mathrm{X}$.

\section{Paper manufacture with nanofibrillated cellulose addition}

Paper sheets were produced by incorporating nanofibrillated cellulose in the proportions of 3, 6 and $9 \%$ by performing a mechanical mixture in a mixer, in addition to the treatment without the addition of nanofibrillated cellulose for subsequent comparison (control), totaling 10 treatments.

The water drainage resistance of the cellulosic pulp was determined with a Schopper Riegler tester before producing the sheets, according to ISO 5267/1.

The paper samples were produced with a Rapid-Köethen type forming station with a drying temperature of $90 \pm 2{ }^{\circ} \mathrm{C}$ and pressure of $40 \mathrm{kPa}$, according to the ISO 5269/2 and T205 sp-02 standards. Five samples were prepared per treatment, with average grammage of $60 \pm 3 \mathrm{~g} / \mathrm{m}^{2}$. 
As specified in the T402-om94 standard, the paper samples were dried and then air-conditioned at a temperature of $23 \pm 2{ }^{\circ} \mathrm{C}$ and relative humidity of $50 \pm 2 \%$ before the physical and mechanical tests.

\section{Physical and mechanical tests}

The acclimatized paper samples were tested to determine the following physical properties: moisture content (T412-om02), grammage (T410-om02), thickness (T411-om97), water absorption (T441-om98), and apparent density (T220-sp01), as well as the mechanical properties of: tensile strength (T404-om92), bursting strength (T403-om02) and internal tearing strength (T414-om98).

The tensile strength was measured through the tensile index, which corresponds to the ratio between the resistance and weight of the sample, expressed in N.m/g. The bursting index is calculated by the ratio between burst strength and sample weight, and is expressed in $\mathrm{Kpa} . \mathrm{m}^{2} / \mathrm{g}$. The internal tearing index is calculated through the ratio between tear strength and sample weight, and is expressed in $\mathrm{mNm}^{2} / \mathrm{g}$. Five samples of each treatment were submitted to each physical and mechanical test.

\section{Statistical analysis}

The factorial analysis of variance of the physical and mechanical properties was performed considering 95\% reliability. This analysis was applied to check if there was a significant influence of the factors corresponding to percentage of nanofibrillated cellulose addition and the number of grinding passes of the nanofibrillated cellulose, and also if there was interaction between these factors. The homogeneity of variances was tested by the Bartlett test, in which all variances of the samples were homogeneous.

\section{RESULTS}

\section{Transmission electron microscopy (TEM)}

Figure 1 (A, B and C) presents TEM images of the fiber after being submitted to the mechanical defibrillation process with 2, 10 and 20 passes through the grinder, respectively.

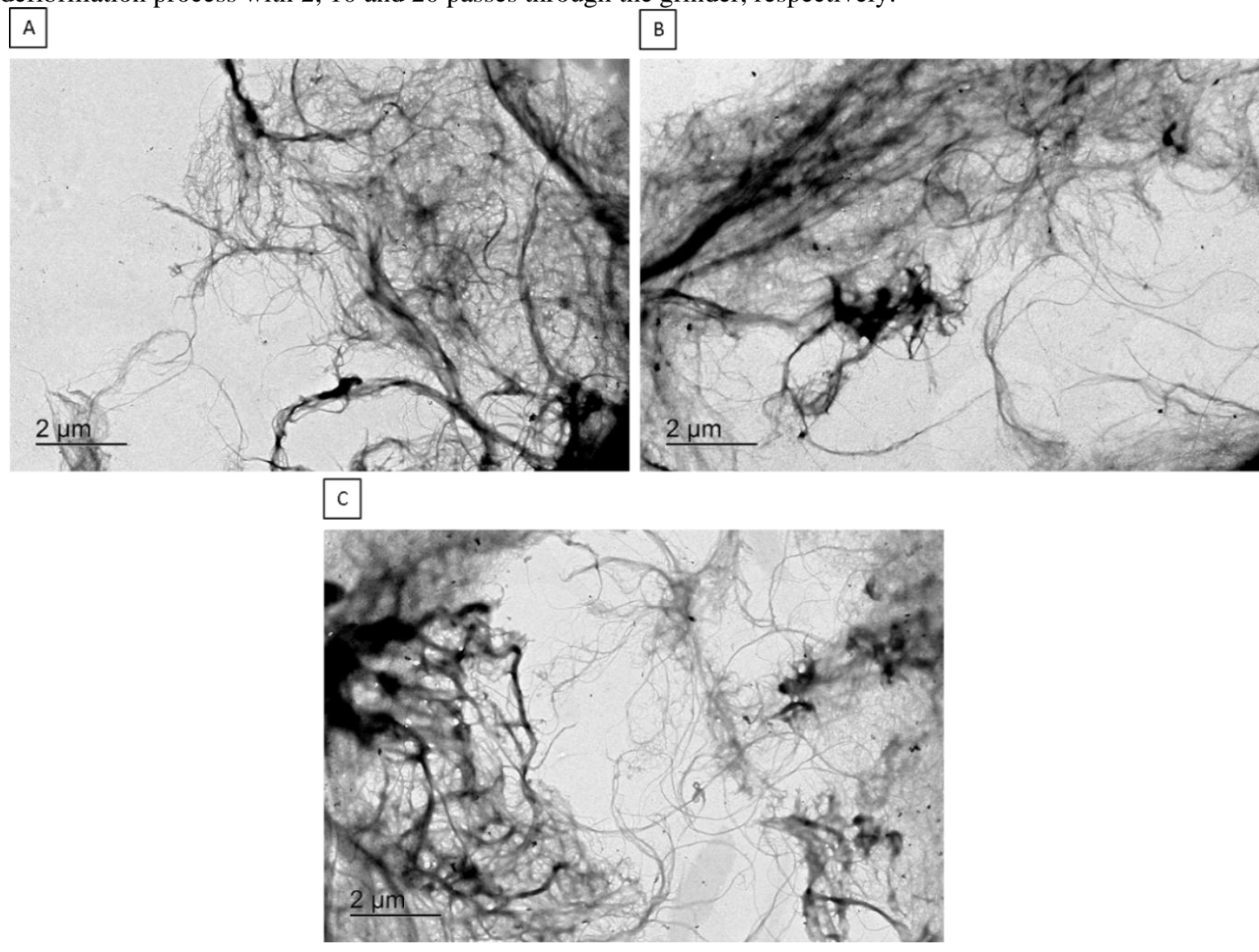

FLORESTA, Curitiba, PR, v. 50, n. 3, p. 1411 - 1420, jul/set 2020. 
Figure 1. Images of cellulose nanofibrils from Eucalyptus sp. obtained by TEM: a) 2 passes; b) 10 passes; c) 20 passes.

Figura 1. Imagens da celulose nanofibrilada de Eucalyptus sp. obtidas por meio do MET: a) 2 passes; b) 10 passes; c) 20 passes.

According to the images acquired through TEM, there were no significant differences between 2, 10 and 20 grinding passes (Figure $1 \mathrm{a}, \mathrm{b}$ and $\mathrm{c}$ ). The TEM investigations show that the nanofibrils present average diameter after the defibrillation varying between approximately 20 and $45 \mathrm{~nm}$ with 2, 10 and 20 passes.

\section{Physical and mechanical properties of the paper}

Figure 2 shows the effect of the relationship between the increase in the number of passes and the percentage addition of nanofibrillated cellulose on the physical properties of the paper samples.

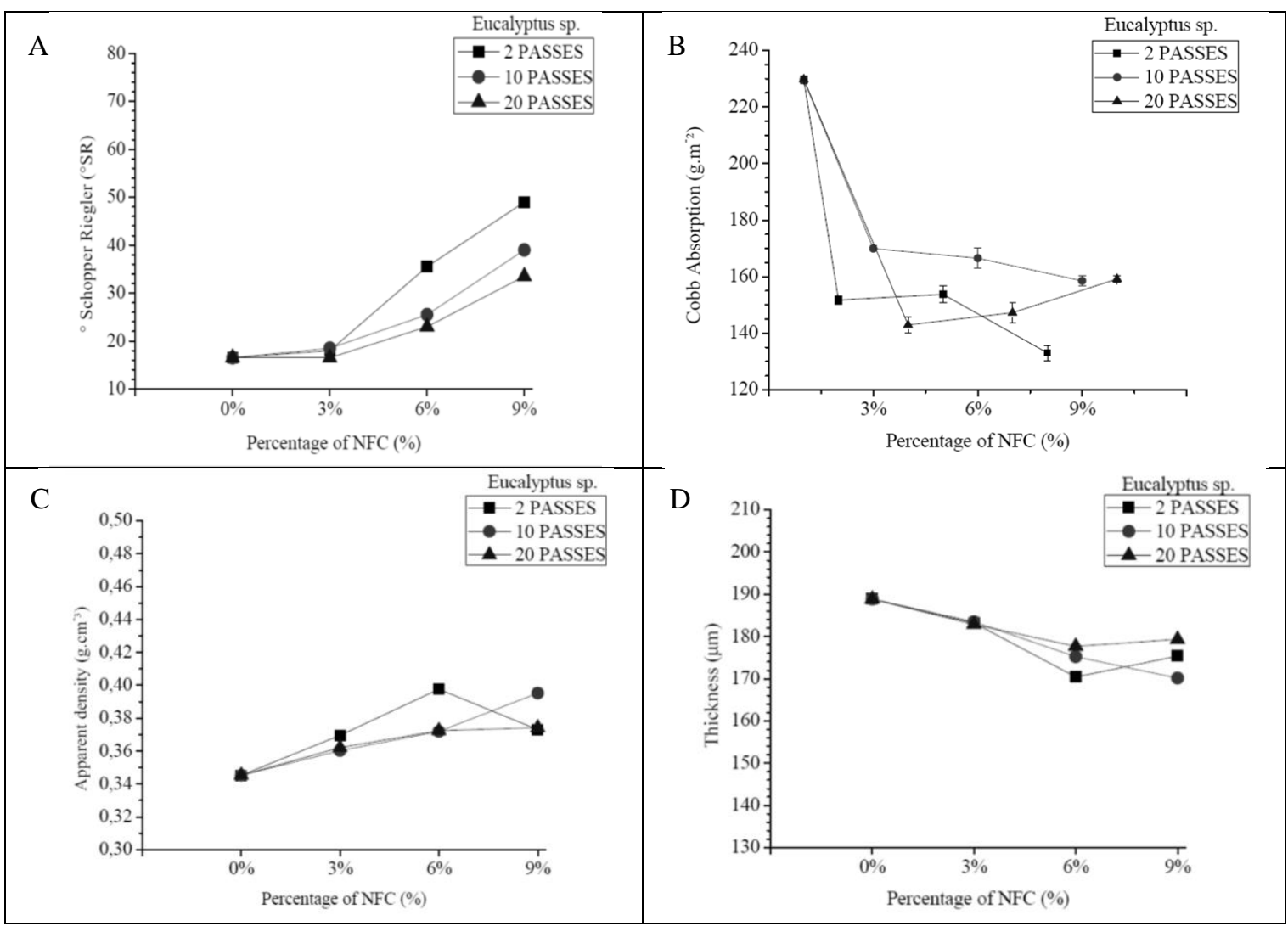

Figure 2. Physical properties of paper produced with NFC after different passes in relation to NFC percentage. In which: A. Schopper Riegler; B. Cobb absorption; C. apparent density; D. thickness.

Figure 2. Propriedades físicas dos papéis produzidos com CNF após diferentes passes em relação a porcentagem de CNF. Em que A. Schopper Riegler; B. absorção Cobb; C. densidade aparente; D. espessura.

Table 1 shows that the Schopper Riegler degree ( $\left.{ }^{\circ} \mathrm{SR}\right)$, water absorption (Cobb 60) and apparent density of the papers were influenced by the different numbers of passes, NFC percentages and the combination of these factors. The paper thickness was only influenced by the NFC percentage.

Table 1. Summary of factorial analysis of variance.

Tabela 1. Resumo da análise de variância fatorial.

\begin{tabular}{ccccc}
\hline Anova & SR & Cobb60 & AD & \multicolumn{2}{c}{ Thickness } \\
& $\boldsymbol{P}$ & $\boldsymbol{P}$ & $\boldsymbol{P}$ & $\boldsymbol{P}$ \\
\hline (NFC) wt\% & $0.0001^{*}$ & $0.0004^{*}$ & $0.0001^{*}$ & $0.0001^{*}$ \\
Number of passes & $0.0001^{*}$ & $0.0001^{*}$ & $0.0130^{*}$ & $0.0623^{\mathrm{ns}}$ \\
NFC wt\% x passes & $0.0001^{*}$ & $0.0001^{*}$ & $0.0001^{*}$ & $0.0646^{\mathrm{ns}}$ \\
\hline
\end{tabular}

$\mathrm{SR}=$ Schopper Riegler degree; $\mathrm{AD}=$ Apparent Density; * corresponds to significant differences ( $\mathrm{p}<0.05$ ), and ns corresponds to non-significant $(\mathrm{p}>0.05)$.

FLORESTA, Curitiba, PR, v. 50, n. 3, p. 1411 - 1420, jul/set 2020. 
An increase of ${ }^{\circ} \mathrm{SR}$ in the paper was observed with the addition of nanofibrillated cellulose with 2,10 and 20 passes. The water absorption by the paper decreased with nanofibrillated cellulose addition with 2, 10 and 20 passes (Figure 2). The density values increased with increasing NFC percentage, except for paper with the addition of 9\% NFC with 2 passes. The values ranged from 0.35 to $0.40\left(\mathrm{~g} . \mathrm{cm}^{-3}\right)$ for treatments E00 and E109, respectively. The paper thickness formed by cellulose nanofibers presented a reduction when compared to the paper without NFC. This behavior was not observed for paper with the incorporation of $9 \%$ nanofibrillated cellulose with 2 and 20 passes.

Table 2 presents the physical properties of the paper in relation to the number of passes through the grinder and the nanofibrillated cellulose percentage addition.

Table 2. Average physical property values of paper.

Tabela 2. Valores médios das propriedades físicas dos papéis produzidos.

\begin{tabular}{|c|c|c|c|c|c|c|c|c|}
\hline \multirow{2}{*}{ Treatment * } & \multicolumn{2}{|c|}{$\mathbf{S R}\left(^{\circ}\right)$} & \multicolumn{2}{|c|}{$\operatorname{Cobb}_{60}\left(\mathrm{~g} \cdot \mathrm{m}-{ }^{2}\right)$} & \multicolumn{2}{|c|}{$\mathrm{AD}\left(\mathrm{g} . \mathrm{cm}^{-3}\right)$} & \multicolumn{2}{|c|}{ Thickness ( $\mu \mathrm{m})$} \\
\hline & $\bar{X}$ & $\Sigma$ & $\bar{X}$ & $\Sigma$ & $\bar{X}$ & $\Sigma$ & $\bar{X}$ & $\Sigma$ \\
\hline E000 & $16.5 \mathrm{~A}$ & 0.1 & $229.7 \mathrm{G}$ & 1.3 & $0.35 \mathrm{~A}$ & 0.01 & $188.9 \mathrm{C}$ & 4.2 \\
\hline E023 & $18.0 \mathrm{~B}$ & 0.3 & 151.7 CD & 1.5 & $0.37 \mathrm{~B}$ & 0.02 & $183.2 \mathrm{BC}$ & 9.5 \\
\hline E026 & $35.5 \mathrm{~F}$ & 0.5 & 153.7 CDE & 3.0 & $0.40 \mathrm{C}$ & 0.01 & $170.4 \mathrm{~A}$ & 9.6 \\
\hline E029 & $49.0 \mathrm{H}$ & 1.0 & $133.0 \mathrm{~A}$ & 2.7 & $0.37 \mathrm{~B}$ & 0.02 & $175.3 \mathrm{AB}$ & 9.0 \\
\hline E103 & $18.5 \mathrm{~B}$ & 0.2 & $169.9 \mathrm{~F}$ & 1.0 & $0.36 \mathrm{AB}$ & 0.01 & $183.5 \mathrm{BC}$ & 6.7 \\
\hline E106 & $25.5 \mathrm{D}$ & 0.5 & $166.5 \mathrm{~F}$ & 3.6 & $0.37 \mathrm{~B}$ & 0.02 & $175.2 \mathrm{AB}$ & 8.1 \\
\hline E109 & $39.0 \mathrm{G}$ & 1.0 & $158.5 \mathrm{DE}$ & 1.7 & $0.40 \mathrm{C}$ & 0.02 & $170.1 \mathrm{~A}$ & 8.2 \\
\hline E203 & $16.5 \mathrm{~A}$ & 0.3 & $142.9 \mathrm{~B}$ & 3.0 & $0.36 \mathrm{AB}$ & 0.01 & $182.9 \mathrm{BC}$ & 5.5 \\
\hline E206 & $23.0 \mathrm{C}$ & 1.0 & 147.3 BC & 3.5 & $0.37 \mathrm{~B}$ & 0.01 & $177.7 \mathrm{AB}$ & 6.1 \\
\hline E209 & $33.5 \mathrm{E}$ & 0.5 & $159.2 \mathrm{E}$ & 1.3 & $0.37 \mathrm{~B}$ & 0.01 & $179.3 \mathrm{~B}$ & 7.0 \\
\hline
\end{tabular}

$\mathrm{SR}=$ Schopper Riegler degree; $\mathrm{AD}=$ Apparent density; $*$ The first and second numbers after the letter represent the number of passes through the grinder and the third number the different NFC percentages. Averages followed by the same lower-case letter in the column are not different by the Tukey test, with a significance of $5 \%$.

The ANOVA summary shows that the tensile, burst and tear indices (Table 3) were significantly influenced by the number of passes $(2,10$ and 20 passes $)(p=0.0001)$, by the nanofibrillated cellulose percentage incorporation $(3,6$ and $9 \%)(\mathrm{p}=0.0001)$ and the combination of these factors.

Table 3. Summary of factorial analysis of variance.

Tabela 3. Resumo da análise de variância fatorial.

\begin{tabular}{cccc}
\hline Anova & Tensile index & Burst index & Tear index \\
\hline \%wt Nanofibrillated celulose (NFC) & $\boldsymbol{p}$ & $\boldsymbol{P}$ & $\boldsymbol{p}$ \\
Number of passes & $0.0001^{*}$ & $0.0001^{*}$ & $0.0001^{*}$ \\
$\%$ wt NFC X no. of passes & $0.0001^{*}$ & $0.0001^{*}$ & $0.0001^{*}$ \\
\hline
\end{tabular}

* corresponds to significant differences $(\mathrm{p}<0.05)$ and $\mathrm{ns}$ corresponds to non-significant $(\mathrm{p}>0.05)$. 


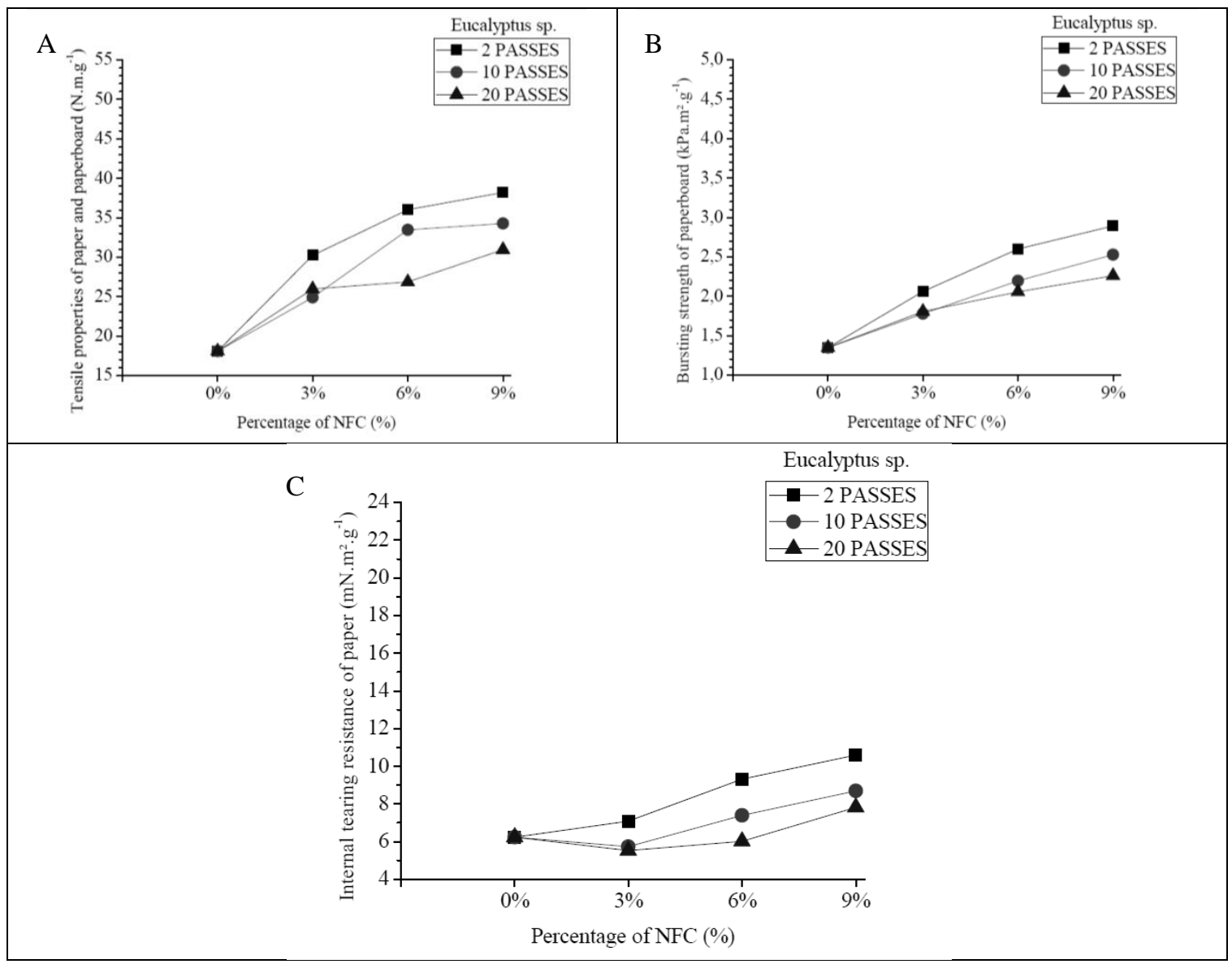

Figure 3. Mechanical properties of paper produced with NFC and different passes in relation to the NFC percentage. In which: A. Tensileindex; B. Burst index; C. Tear index.

Figura 3. Propriedades mecânicas dos papéis produzidos com CNF e diferentes passes em relação a porcentagem de CNF. Onde A. índice de tração; B. Índice de arrebentamento; C. Índice de rasgo.

The highest values of tensile, burst and tear indices were observed for the paper produced with 2 passes. A gradual increase occurred with the increase in the nanofibrillated cellulose percentage (Figure 3). The highest values were obtained for $9 \%$ NFC (Table 4).

Table 4. Average mechanical properties of paper.

Tabela 4. Valores médios para as propriedades mecânicas dos papéis.

\begin{tabular}{|c|c|c|c|c|c|c|}
\hline \multirow[t]{2}{*}{ Treatment } & \multicolumn{2}{|c|}{ Tensile Index (N.m.g-1) } & \multicolumn{2}{|c|}{$\begin{array}{l}\text { Burst Index } \\
\left(\text { Kpa.m². } \mathrm{g}^{-1}\right)\end{array}$} & \multicolumn{2}{|c|}{$\begin{array}{c}\text { Tear Index }\left(m n . m^{2} \cdot g\right. \\
1)\end{array}$} \\
\hline & $\bar{X}$ & $\Sigma$ & $\bar{X}$ & $\Sigma$ & $\bar{X}$ & $\sigma$ \\
\hline E000 & $18.1 \mathrm{~A}$ & 1.9 & $1.3 \mathrm{~A}$ & 0.1 & $6.2 \mathrm{AB}$ & 0.3 \\
\hline E023 & $30.2 \mathrm{CDE}$ & 2.2 & $2.1 \mathrm{C}$ & 0.1 & $7.1 \mathrm{BC}$ & 0.4 \\
\hline E026 & $36.0 \mathrm{FG}$ & 4.7 & $2.6 \mathrm{E}$ & 0.2 & $9.3 \mathrm{E}$ & 0.4 \\
\hline E029 & $38.2 \mathrm{G}$ & 4.6 & $2.9 \mathrm{~F}$ & 0.1 & $10.6 \mathrm{~F}$ & 0.5 \\
\hline E103 & $24.9 \mathrm{~B}$ & 1.9 & $1.8 \mathrm{~B}$ & 0.1 & $5.7 \mathrm{~A}$ & 0.5 \\
\hline E106 & $33.5 \mathrm{EF}$ & 3.2 & $2.2 \mathrm{CD}$ & 0.2 & $7.4 \mathrm{C}$ & 0.6 \\
\hline E109 & $34.3 \mathrm{EFG}$ & 3.6 & $2.5 \mathrm{E}$ & 0.1 & 8.7 DE & 0.5 \\
\hline E203 & $26.0 \mathrm{BC}$ & 2.9 & $1.8 \mathrm{~B}$ & 0.1 & $5.5 \mathrm{~A}$ & 0.4 \\
\hline E206 & $26.9 \mathrm{BCD}$ & 3.2 & $2.1 \mathrm{C}$ & 0.1 & $6.0 \mathrm{~A}$ & 0.1 \\
\hline E209 & $31.0 \mathrm{DE}$ & 2.7 & $2.3 \mathrm{D}$ & 0.2 & $7.8 \mathrm{CD}$ & 0.6 \\
\hline
\end{tabular}

*The first and second numbers after the letter represent the number of passes through the grinder and the third number the different NFC percentages. Averages followed by the same lower-case letter in the column are not different by the Tukey test, with a significance of $5 \%$

FLORESTA, Curitiba, PR, v. 50, n. 3, p. 1411 - 1420, jul/set 2020.

Potulski, D. C. et.al.

ISSN eletrônico 1982-4688

DOI: $10.5380 /$ rf.v50 i3. 59251 
Table 5 shows the percentage change in the mechanical properties of the paper with the addition of nanofibrillated cellulose. The incorporation of $9 \%$ nanofibrillated cellulose obtained with 2 passes through the Masuko grinder was notable for increasing the tensile index $(111.35 \%)$, burst index $(114.53 \%)$ and tear index (70.13\%) of the paper made with virgin Eucalyptus sp. fibers.

The smallest percentages obtained were for the incorporation of $3 \%$ of nanofibrillated cellulose with 10 and 20 passes through the grinder.

Table 5. Percentage variation of mechanical properties of paper with the addition of NFC in relation to treatment without addition.

Tabela 5. Variação em porcentagem das propriedades mecânicas dos papéis com adição de celulose nanofibrilada em relação ao sem adição.

\begin{tabular}{cccc}
\hline Treatment & Tensile Index (\%) & Burst Index (\%) & Tear Index(\%) \\
\hline E023 & 67.28 & 52.85 & 13.79 \\
E026 & 99.29 & 92.90 & 49.52 \\
E029 & 111.35 & 114.53 & 70.13 \\
\hline E023 & 37.76 & 31.85 & -7.90 \\
E106 & 85.11 & 63.01 & 18.64 \\
E109 & 89.63 & 87.58 & 39.51 \\
\hline E103 & 43.63 & 34.16 & -11.30 \\
E206 & 48.58 & 52.36 & -3.42 \\
E209 & 71.26 & 67.62 & 25.63 \\
\hline
\end{tabular}

*The first and second numbers after the letter represent the number of passes through the grinder and the third number the different NFC percentages.

\section{DISCUSSION}

\section{Transmission electron microscopy (TEM)}

In considering nanofibrillated cellulose to be nanostructures with smaller diameter than $100 \mathrm{~nm}$ (VIANA et al., 2017), the mechanical defibrillation process with 2 passes through the mill was sufficient to obtain nanometric scale materials.

Other authors have also observed the same tendency, such as Wang et al. (2013), who obtained cellulose nanofibrils with diameter between 30 and $100 \mathrm{~nm}$ after 20 mill passes at 1,600 rpm and consistency of $1 \%$. Viana et al. (2017) did not observe significant differences between nanofibrillated cellulose diameters obtained with 2 , $5,10,20,30$ and 40 passes through the grinder at $1 \%$ consistency. Fonseca et al. (2016) obtained diameters of less than $40 \mathrm{~nm}$. The authors observed that it was possible to increase the swelling capacity with the reduction of the fibril dimensions, since the fiber surface was larger in relation to volume.

The ratio between the fiber length and diameter in NFC is high, enabling better capacity to form a stiff and homogeneous network which produces a paper with lower porosity, high density and resistance properties (CAMPANO et al., 2018).

\section{Physical and mechanical properties of the paper}

NFC promotes an increase in the number of hydrogen bonds, which in turn increases the drainage resistance. The reason is that the cell wall surface is more exposed, meaning that the hydration rate is higher, and the flexibility of the fibers forming the sheet. The results show that the addition of nanofibrillated cellulose can be used to reduce the refining time, since resistance to drainage increased (KALIA et al., 2014).

The increase in ${ }^{\circ} \mathrm{SR}$ has also been reported in other studies. González et al. (2012) observed an increase from 18 to $54^{\circ} \mathrm{SR}$ in paper produced with short-fiber cellulose and with the incorporation of $9 \%$ nanofibrillated cellulose.

The water absorption of the paper in this study decreased, as reported by other authors such as VIANA et al. (2017). This can be explained by the very compact structure and low porosity of nanostructured films which decrease the water penetration.

The presence of NFC in paper increases the interaction between the cellulose fibers and promotes better rearrangement, filling the empty spaces between the fibers during paper production, and providing a more uniform and compact structure (GONZÁLEZ et al., 2012). This explains the formation of thinner paper with greater density with the same grammage.

FLORESTA, Curitiba, PR, v. 50, n. 3, p. 1411 - 1420, jul/set 2020. 
This behavior was reported by Sehaqui et al. (2011) in studying the properties of nanostructured paper with the addition of 0 to $12 \%$ of cellulose micro and nanofibers. Potulski et al. (2018) verified an increase in the density of paperboard delignified from 0.43 to $0.46 \mathrm{~g} . \mathrm{cm}^{-3}$ with the addition of $6 \%$ of nanofibrillated cellulose.

Greater paper density can occur due to the formation of a large amount of fiber-nanofiber bonds because the defibrillation process exposes microfibrils. Tensile and burst properties directly depend on the interfiber bonds and the formation and structure of the paper. Fibers with smaller dimension and/or nanofibrillated fibers have increased specific area and more contact points, increasing the number of bonds. The increase of these bonds raises the apparent density, as well as the tensile and burst strengths, although to a limited extent in all cases.

In a study on the potential application of nanofibrillated cellulose to improve paper strength, Sehaqui et al. (2011) observed a 64\% increase in tensile index with the addition of 10\% nanofibers. González et al. (2012) studied the incorporation of nanofibrillated cellulose in unrefined Eucalyptus cellulosic pulp. The authors found average values for the tensile index of $31.9 \mathrm{~N} . \mathrm{m}^{-1} \mathrm{~g}^{-1}$ with the addition of $3 \%$ of nanofibrillated cellulose and 42.8 N.m.g ${ }^{-1}$ with the addition of $6 \%$. Potulski et al. (2014) also found an increase in the tensile index in bleached paper of Eucalyptus sp. with 5\% nanofibrillated cellulose.

Torres et al. (2005) obtained a tensile index near $50 \mathrm{~N} \cdot \mathrm{m} . \mathrm{g}^{-1}$ for non-bleached long-fiber paper with Schopper Riegler grade $25^{\circ}$, while in this study we obtained a tensile index close to $46.8 \mathrm{~N} \cdot \mathrm{m} \cdot \mathrm{g}^{-1}$ with addition of 9\% nanofibrillated cellulose and 2 passes through the grinder. Thus, it would be possible to maintain the same tensile strength of the paper by replacing the packaging produced with long fibers subjected to a refining process by recycled short fibers with the addition of nanofibrillated cellulose.

The tensile index found by Wistara and Young (1999) was higher than in the present study, ranging from 79.99 to 97.77 (N.m.g ${ }^{-1}$ ). Campano et al. (2018) reported that the addition of nanofibrillated cellulose increased the mechanical strength characteristics of paper.

The trend of increased burst index with the addition of nanofibrillated cellulose has also been reported by other authors. González et al. (2012) observed mean burst indices of $2.2 \mathrm{kPa} \cdot \mathrm{m}^{2} \cdot \mathrm{g}^{-1}$ and $2.9 \mathrm{kPa} \cdot \mathrm{m}^{2} \cdot \mathrm{g}^{-1}$ for delignified Eucalyptus pulp with $3 \%$ and $6 \%$ addition of nanofibrillated cellulose, respectively. The results reported by the authors are similar to those found in this study, considering possible intrinsic differences of materials and processes.

Regarding the tear index, a significant influence of the incorporation of the nanofibrillated cellulose was observed (Table 4). The study by Manfredi et al. (2012) showed inferior performance to the results found for this index of Eucalyptus sp.

According to Viana et al. (2017), the process of obtaining nanofibrillated cellulose by mechanical defibrillation separates the microfibrils, but also reduces its length, which can negatively influence some properties, especially the tear resistance. Stelte and Sanadi (2009) also observed a reduction in the length of the nanofibrils due to high shear forces in treatments involving more than 10 passes through the mill Masuko grinder. Iwamoto et al. (2007) also noted that the increase in the number of passes caused degradation of the cellulose in nanofibrils due to the reduced degree of crystallinity and polymerization of the cellulose, causing a significant decrease in the mechanical properties.

\section{CONCLUSION}

- The physical and mechanical properties of the paper sheets were influenced by the number of passes to produce nanofibrillated cellulose by mechanical defibrillation, the nanofibrillated cellulose percentage incorporation and the combination of these two factors.

- For the physical properties, the addition of nanofibrillated cellulose in the paper reduced the thickness, increased the apparent density and decreased the water absorption.

- For the mechanical properties, the addition of nanofibrillated cellulose in the paper caused an increase in the tensile, burst and tear strength indices.

- The greatest increase in paper strength properties was observed with the addition of $9 \%$ nanofibrillated cellulose and 2 passes through the grinder.

- Nanofibrillated cellulose obtained with 10 and 20 passes for 3, 6 and 9 wt $\%$ added to the paper presented less significant increments in the strength properties.

\section{REFERENCES}

CAMPANO, C.; MERAYO, N.; BALEA, A.; TARRÉS, Q.; DELGADO-AGUILAR, M.; MUTJE, P.; NEGRO, C.; BLANCO, A. Mechanical and chemical dispersion of nanocellulose to improve their reinforcing effect on recycled paper. Cellulose, v. 25, p. 269-280, 2018.

FLORESTA, Curitiba, PR, v. 50, n. 3, p. 1411 - 1420, jul/set 2020. 
CHEN, J. Y.; SUN, L.; NEGULESCU, I.; XU, B. Fabrication and evaluation of regenerated cellulose/nanoparticle fibers from lignocellulosic biomass. Biomass and Bioenergy, Spain. v. 101, p. 1-8, 2017.

FENGEL, D.; WEGENER, G. Wood: chemistry, ultrastructure, reactions. Walter de Gruyter, v. 613, p. 196082, 1984.

FONSECA, C. S.; SILVA, T. F.; SILVA, M. F.; OLIVEIRA, I. R. C.; MENDES, R. F.; HEIN, P. R. G.; MENDES, L. M.; TONOLI, G. H. D. Micro/nanofibrilas celulósicas de Eucalyptus em fibrocimentos extrudados. Cerne, Lavras. v. 22, n. 1, p. 59-68, 2016.

GONZÁlEZ, I.; BOUFI, S.; PÈlACH, M. A.; ALCALÀ, M.; VILASECA, F.; MUTJÉ, P. Nanofibrillated Cellulose as paper additive in Eucalyptus pulps. Nanofibrillated cellulose paper additive, Bioresources, Raleigh. v. 4, n. 7, p.5167- 5180, 2012.

INDÚSTRIA BRASILEIRA DE ÁRVORES - IBÁ. Relatório 2017, 80 p. 2017.

INTERNATIONAL ORGANIZATION FOR STANDARDIZATION. Pulps: determination of drainability. Part 1: Schopper-Riegler method. Genève, 1979. 5p. (ISO 5267-1: 1979).

Pulps: Preparation of laboratory sheets for physical testing. Part 2: Rapid-Köthen method. Genève, 2004. (ISO 5269-2: 2004)

IWAMOTO, S.; NAKAGAITO, A.N.; YANO, H. Nano-fibrillation of pulp fibers for the processing of transparent nanocomposites. Applied Physics A, Berlin. v. 89, p. 461-466, 2007.

JONOOBI, M.; MATHEW, A.P.; OKSMAN, K. Producing low-cost nanofibrillated cellulose from sludge as new source of raw materials. Industrial Crops and Products. Elsevier. v. 40, p. 232- 238, 2012.

KALIA, S.; THAKUR, K.; CELLI, A.; KIECHEL, M. A.; SCHAUER, C. Nanofibrillated cellulose: surface modification and potential applications. Colloid and Polymer Science, Elsevier. v. 292, n. 1, p. 5-31, 2014.

KHALIL, H. P. S. A.; DAVOUDPOURA, Y.; NAZRUL ISLAM, Md.; MUSTAPHA, A.; SUDESH, K.; DUNGANIA, R.; JAWAID, M. Production and modification of nanofibrillated cellulose using various mechanical processes: A review. Carbohydrate Polymers, Elsevier. v.99, p. 649-665, 2014.

MANFREDI, M.; OLIVEIRA, R. O.; SILVA, J. C. Melhoramento das propriedades de papéis reciclados através da ultrassonificação das fibras e adição de xilanas. Revista Árvore, Viçosa. v. 36, n. 4, 2012.

MOHAMMADKAZEMI, F.; DOOSTHOSEINI, K.; GANJIAN, E.; AZIN, M. Manufacturing of bacterial nanocellulose reinforced fiber-cement composites. Construction and Building Materials, Elsevier. v.101, p.958-964, 2015.

OSONG, S. H.; NORGREN, S.; ENGSTRAND, P. Processing of wood-based microfibrillated cellulose and nanofibrillated cellulose, and applications relating to papermaking: a review. Cellulose, v. 23, n. 1, p. 93-123, 2016.

POTULSKI, D. C.; LOPES, M. S.; MUNIZ, G. I. B.; CARNEIRO, M. E.; ANRADE, A. S. influência da adição de celulose nanofibrilada (CNF) nas propriedades ópticas e físicas do papel. Biofix Scientific Journal, Curitiba. v.1, n.1, p. 122-129, 2018.

POTULSKI, D. C.; MUNIZ, G. I. B. D.; KLOCK, U.; ANDRADE, A. S. D. Influência da incorporação de celulose microfibrilada nas propriedades de resistência mecânicas do papel. Scientia Forestalis, São Paulo. v. 42, n. 103, p. 345-351, 2014.

SEHAQUI, H.; ALLAIS, M.; ZHOU, Q.; BERGLUND, L. A. Wood cellulose biocomposites with fibrous structures at micro- and nanoscale. Composites Science and Technology, v. 71, n. 3, p. 382-387, 2011.

STELTE, W.; SANADI, A.R. Preparation and Characterization of Nanofibrillated celluloses from Two Commercial Hardwood and Softwood Pulps. Industrial \& Engineering Chemistry Research, v. 48, p.1121111219, 2009.

TORRES, L. F.; MELO, R.; COLODETTE, J. L. Bleached kraft pulp production from Pinus tecunumanii (Eguiluz e Perry). Revista Árvore, v. 29, n. 3, p. 489-494, 2005.

VIANA, L. C.; MUNIZ, G. I. B.; MAGAlHAES, W. L. E. Propriedades físicas e mecânicas de filmes nanoestruturados obtidos a partir de polpa Kraft de Pinus sp. não branqueada. Scientia Forestalis, v. 45, p. 653662, 2017.

FLORESTA, Curitiba, PR, v. 50, n. 3, p. 1411 - 1420, jul/set 2020. 
WANG, H.; LI, D.; ZHANG, R. Preparation of ultralong nanofibrillated celluloses and optically transparent nanopapers derived from waste corrugated paper pulp. Bioresources, v.8, n.1, p.1374-1384, 2013.

WISTARA, N.; YOUNG, R. A. Properties and treatments of pulps from recycled paper. Part I. Physical and chemical properties of pulps. Cellulose, v. 6, p. 291-324, 1999.

YOO, S.; HSIEH, J. S. Enzyme-assisted preparation of fibril- lated cellulose fibers and its effect on physical and mechanical properties of paper sheet composites. Industrial Engineering Chemistry Research, v. 49, n.5, p. 2161-2168, 2010.

ZIMMERMANN, T.; BORDEANU, N.; STRUB, E. Properties of nanofibrillated cellulose from different raw materials and its reinforcement potential. Carbohydrate Polymers, v. 79, n. 4, p. 1086-1093, 2010. 